\title{
Správa z inauguračnej prednášky doc. Mgr. et Mgr. Miroslava Lysého, PhD.
}

S pánom docentom Miroslavom Lysým som sa bližšie zoznámil na hodinách Právnej historiografie, prednášanej $\mathrm{v}$ rámci prvého ročníka doktorandského študijného programu Teória a dejiny štátu a práva. Z obsahového hl’adiska mi v pamäti utkvela vysoká kvalita jeho výkladu, ktorý sa vyznačoval príslovečnou vecnostou, avšak bol spestrený aj rôznymi zaujímavost'ami z preberanej matérie. Tieto hodiny boli pre mňa mimoriadne vzácne a ako študent na nich rád spomínam. Odchádzal som z nich s nenásilne implantovaným vnuknutím dozvediet' sa o preberanej téme viac. Ked’ nám bolo o pár rokov neskôr dopriate spolupracovat' na spoločnej kolektívnej monografii, mohol som opät' zblízka sledovat' jeho umiernený, rozvážny prístup $\mathrm{k}$ riešeniu bežných problémov a s úctou som pozoroval jeho niveau kariérneho diplomata. Vojtech Hatala, na Slovensku mimoriadne uznávaný profesor trestného práva, často opakoval mladým asistentom, že „,niekedy nie je ani takým problémom profesúru získat', ale problémom je vždy a v každom smere naozaj byt' univerzitným profesorom. “1 Práve preto som si dovolil začat’ túto správu drobnou sugestívnou spomienkou ako osobné svedectvo k vyššie uvedenému.

Inauguračná prednáška docenta Lysého bola pôvodne naplánovaná na 10. septembra 2020 v Amfiteátri Právnickej fakulty. Ked' sa však tento dátum blížil, zdalo sa, že Slovenskú republiku i celý svet postihla tzv. druhá vlna epidémie vírusu SARS-CoV-2. Ked’že Právnická fakulta Univerzity Komenského už skôr flexibilne reagovala na vzniknutú situáciu presunom do on-line priestoru, opätovne st’ažená situácia nepredstavovala skutočnost', ktorá by jej akademickú obec negatívne prekvapila. Napokon, už v letnom semestri akademického roka 2019/20 sa na Právnickej fakulte uskutočnili viaceré obhajoby dizertačných prác, habilitačných a inauguračných konaní vo forme on-line prenosu prostredníctvom aplikácie „Microsoft Teams“ (z odboru dejín štátu a práva spomeňme habilitačné a inauguračné konanie docenta Róberta Brtka, habilitačné konanie doktorky Zuzany Mlkvej Illýovej, či doktora Martina Skaloša).

Z toho dôvodu sa aj terajšie zasadnutie Vedeckej rady Právnickej fakulty Univerzity Komenského 10. septembra 2020 prenieslo do pohodlia kancelárií, či príbytkov zúčastnených aktérov, a to vrátane inauguračnej prednášky docenta Miroslava Lysého, ktorá na tomto zasadnutí odznela. Elektronická platforma zasadnutia umožnila aj v týchto nároč-

LAZAR, J. Spomienka na priatel'a. In: VLADÁR, V. (ed.). Perpauca terrena blande honori dedicata. Pocta Petrovi Blahovi k nedožitým 80. narodeninám. Trnava: Právnická fakulta Trnavskej Univerzity, 2019, s. 16. 
ných časoch participáciu viacerých hostí z katedry inauguranta, odborníkov z historickej obce, ale aj širokej verejnosti.

Pán dekan Právnickej fakulty doc. JUDr. Eduard Burda, PhD. uvítal na zasadnutí Vedeckej rady všetkých prítomných. Presne o 14,30 hod. odovzdal slovo predsedovi inauguračnej komisie, pánovi prof. JUDr. Jozefovi Klimkovi, DrSc. Pán profesor postupne predstavil členov komisie a oponentov. Inauguračnú komisiu tvoril prof. JUDr. Michal Skřejpek, DrSc. z Právnickej fakulty Univerzity Karlovej v Prahe, prof. JUDr. PhDr. Miloš Večeřa, CSc. z Právnickej fakulty Masarykovej univerzity v Brne a napokon prof. JUDr. Alexander Bröstl, CSc., z Právnickej fakulty Univerzity Pavla Jozefa Šafárika v Košiciach. V tejto súvislosti profesor Klimko oboznámil Vedeckú radu s kladným stanoviskom inauguračnej komisie, ktorá na svojom zasadnutí 14. júla 2020 dôkladne preskúmala všetky podklady a skonštatovala, že inaugurant spĺn̆a všetky podmienky a kritériá pre vymenovanie za profesora.

Za oponentov boli vymenovaní prof. JUDr. Peter Mosný, CSc., významný odborník z oblasti dejín štátu a práva, bývalý profesor na Právnickej fakulte Trnavskej univerzity, prof. JUDr. Ladislav Vojáček, CSc. z Právnickej fakulty Masarykovej univerzity, a prof. JUDr. Matúš Nemec, PhD. z domovskej Právnickej fakulty Univerzity Komenského. Napokon, profesor Klimko pristúpil k charakteristike inauguranta. Vedeckú radu a hostí oboznámil s dosiahnutým vzdelaním docenta Lysého (v roku 2003 úspešne ukončil magisterské štúdium na Filozofickej fakulte Univerzity Komenského v Bratislave v odbore archeológia - história, v roku 2006 obhájil dizertačnú prácu na tejto Filozofickej fakulte v odbore všeobecné dejiny, v roku 2020 graduoval na Právnickej fakulte Trnavskej univerzity v odbore právo, docentom sa stal v roku 2015). Profesor Klimko sa tiež dotkol publikačnej a pedagogickej práce inauguranta.

Potom predstavil tému inauguračnej prednášky Miroslava Lysého s názvom „Poňatie národa v slovenských právnych dejinách“" a odovzdal mu slovo.

Docent Lysý v úvode časovo ohraničil svoju prednášku na obdobie Uhorského král’ovstva. Výber témy zdôvodnil viacerými okolnost’ami, najmä svojím dlhodobým záujmom o etnogenézu. Ďalej poukázal na skutočnosti, ktoré do tejto sféry vnášajú aktualizačný moment, napríklad na znenie platného základného zákona Mad’arska, ktorý zdôrazňuje kontinuitu ich terajšieho štátu s Uhorským král'ovstvom. Zároveň upozornil na iné historické reminiscencie, pričom za všetky možno spomenút' problematiku Trianonskej mierovej zmluvy, kde tiež prevláda snaha prezentovat' Uhorsko ako mad’arský národný štát.

Z načrtnutého stavu odvodil dve protichodné tézy, ktorými možno charakterizovat' etnický ráz Uhorska. Jednak ide o jeho vnímanie ako štátu mad’arského národa. Túto optiku reprezentujú napríklad názory mad’arského historika Jánosa Karácsonyiho. Podl’a neho Slováci prišli do Uhorska v 15. storočí ako príslušníci českej národnosti. To znamená, že prítomnost' mnohých národností v Uhorsku vysvetl'oval ako dôsledok vývoja novovekých dejín. ${ }^{2} \mathrm{Na}$ druhej strane vystupuje Uhorsko už od samého vzniku ako mnohonárodnostný štát. Nakoniec, Uhorsko bolo označované za súčast' Sklavínie, teda zeme Slovanov.

Na takto vymedzenom základe si inaugurant jedinečným spôsobom vytvoril hypotézu a vedeckú otázku, ktorú d’alej analyzoval. Pri riešení nastoleného problému sa opieral

2 KARÁCSONYI, J. Történelmi jogunk hazánk területi épségéhez irta. Budapest: Szent István Társulat, $1921,160 \mathrm{~s}$. 
o znenie právnych a neprávnych prameňov. Podotkol, že predmetná otázka bola vždy predmetom interdisciplinárneho výskumu, okrem historiografie ju bližšie skúmala aj jazykoveda, či archeológia. Pritom je pozoruhodné, že hoci mad'arskí aj slovenskí vedci väčšinou používali rovnaké metódy, dospievali k diametrálne rozdielnym názorom.

Za významný prameň svojho rozboru označil docent Lysý privilégiá z 13. storočia. Za zmienku stojí Zlatá bula Ondreja II. servientom z roku 1222, kde sa uvádza: „Nech hostia akéhokol'vek národa žijú podl’a slobody, ktorá im bola udelená na začiatku.“ Zmienený prameň je svedectvom toho, že hostia (teda tí, z ktorých sa formuje najmä mestské obyvatel'stvo) boli v Uhorsku prítomní už v danom období. Podl'a renovácie Zlatej buly Ondreja II. šl'achticom z roku 1231 bola aj šl'achta v 13. storočí vnímaná ako etnicky rôznorodé spoločenstvo.

Z rôznych d'alších privilégií pre hostí a mešt'anov vyplýva, že multietnicita bola prirodzenou súčast’ou Uhorska. Hoci privilégium pre Hronský Beňadik z roku 1217 je v súčasnosti pokladané za falzum zo 14. storočia, bez ohl'adu na to sa v ňom uvádza: ,chceme... aby l'udia akéhokol'vek národa, teda Sasi, Mad'ari, Slováci alebo iní (...) nech sa navždy tešia výhodám takej slobody, akú naši hostia usadení v Pešti, Stoličnom Belehrade alebo v Budíne pokojne užívajú z král'ovskej moci.“"

Drobnú ukážku z praxe stredovekých miest inaugurant poskytol na príklade Budínskej právnej knihy, kde mal richtár (spravidla nemeckej národnosti) po zvolení zložit túto predpísanú prísahu: „Prisahám Bohu všemohúcemu, a nášmu milostivému pánovi, král’ovi Uhorska (...) a mestu Budín, Nemcom a Uhrom..."V tomto kontexte Lysý d'alej spomenul obvod Sasov na Spiši, ktorí sa mohli riadit’ vlastným právom (Zipser Willkür), ale tiež etnický fenomén Sedmohradska, územia pokladaného za úniu troch národov: Sikulov, Mad'arov a Sasov.

Uvedené tvrdenia inaugurant d'alej rozvíjal v tom zmysle, že multinacionalizmus možno pokladat' za jeden $\mathrm{z}$ nástrojov panovníka $\mathrm{v}$ rámci podpory kolonizačnej politiky. Tieto princípy prirodzene prenikli aj do uhorského práva. Svoje úvahy o etnickej diverzite potvrdil aj zmienkou z Opus Tripartitum, vzt’ahujúcu sa na neprivilegovanú skupinu obyvatel'stva. Verböci písal o poddaných ako o skupine rôzneho etnického pôvodu. ${ }^{3}$

V d’alšom priebehu prednášky inaugurant zosumarizoval dôsledky, aké mala prítomnost' mnohých národov pre uhorský štát. Upozornil na to, že v Uhorsku existovala presná hierarchia národov. Na vrchole pomyselnej pyramídy stála uhorská šlachta. Jej príslušníci mali rôzny etnický pôvod, hoci spravidla sa hlásili k uhorskej príslušnosti (natio Hungarica) a teda aj k Starým Mad'arom. Hlásenie sa k uhorskej etnicite bolo pre šl'achtu mimoriadne dôležité z hl'adiska udržania jej výsad, dokonca to chápali ako jednu zo záruk svojej slobody. Šl'achta pritom nebola len obyčajným reprezentantom uhorského národa, ale zároveň predstavovala aj l’ud (populus). Predmetné chápanie vychádza od Ciceróna, od ktorého to prevzal vel'ký encyklopedista Izidor zo Sevilly, jeho závery následne prevzali d'alší učenci v stredoveku. Popri šl'achte v Uhorsku žili privilegované etnické spoločenstvá, ktoré sa mohli spravovat' vlastným právom (najmä Sasi, Nemci). Napokon tu boli poddanské národy (Mad'ari, Slováci).

3 Tripartitum III, 25, 1: „Ich stav je mnohoraký, lebo niektorí sú Uhri, iní Sasi a Nemci, d’alší Česi a Slováci, ktorí vyznávajú krest’anskú vieru. Okrem toho sú niektorí Valasi a Rusi, niektorí obyvatelia Rašky, alebo Srbi a Bulhari, ktorí veria gréckym bludom.“" 
Za mimoriadne zaujímavý a podnetný možno označit' výklad inauguranta o zániku pertraktovaného chápania mnohonárodného uhorského štátu. Inaugurant ho vníma ako dôsledok pádu partikularizmu koncom 18. storočia, kedy požiadavky modernej doby bazírovali na zjednotení drobných častí krajiny a etnických skupín, ktorými bolo pred tým Uhorské král'ovstvo tvorené. Za mimoriadne dôležitý aspekt v tomto procese označil aj to, že v Uhorsku modernizačná iniciatíva smerovala - „zhora“ - od uhorskej šl’achty, ktorá sa stotožňovala práve s uhorským národom. Šl'achta sa preto začala postupne stotožňovat' s mad'arským jazykom. Z toho vyplýva prvoplánovo prekvapivý, ale do kontextu výborne zasadený a logický záver, že mad’arizácia bola sprievodným javom zrovnoprávnenia občanov pred zákonov v Uhorsku a zároveň aj všeobecnej modernizácie spoločnosti a reformy práva. Tieto snahy boli zavŕšené zákonným článkom XLIV z roku 1868 o zrovnoprávnení národností, ktorý vychádzal z konceptu jednotného mad'arského národa, d’alej sa skladajúceho z národností. Zákon im síce priznával určitý súbor práv, ale $\mathrm{v}$ praxi sa nedodržiavali.

V závere docent Lysý zhrnul tézy svojej prednášky, podl'a ktorých bolo Uhorsko v právnych i neprávnych prameňov už od vrcholného stredoveku charakterizované ako multinárodné, preto rozhodne nemožno súhlasit' s teóriami, že tento jav vznikol až v novoveku.

Upozornil na to, že etnický pôvod a stavovská príslušnost' bola v Uhorsku úzko prepojená. Z hl'adiska legislatívy sa Uhorsko stalo štátom jedného národa až od roku 1868 a táto skutočnost' spôsobila, že sa tento útvar negatívne zapísal do našej historickej pamäte. Svoju prednášku ukončil citátom prvého uhorského král'a, svätého Štefana: „Král'ovstvo jedného jazyka a mravu je slabé a krehké.“

Po odznení inauguračnej prednášky pán profesor Klimko vyzval oponentov, aby predniesli svoje posudky. Ako prvý sa slova ujal pán profesor Mosný. Docenta Lysého charakterizoval „ako zodpovedného, skromného až nenápadného, usilovného, s neutíchajúcou túžbou po d'alšom vzdelávaní sa, poctivého vedátora rýdzeho charakteru“. ${ }^{4}$ Následne svoj posudok predniesol profesor Vojáček, ktorý so sebe vlastnou decentnostou uviedol, že v osobe inauguranta ,se propojují ideální odborné předpoklady pro úspěšné působení v oboru právní historiografie a starší právní historiografie zvlášt' - vysokoškolské právnické a historické vzdělání. Jeho působení na právnické fakultě také pootevírá prostor pro lepší porozumění mezi obecnými historiky a právními historiky. " ${ }^{5}$ Napokon, tretí oponent - pán prof. JUDr. Matúš Nemec, PhD. - vyzdvihol inaugurantov zmysel pre praktickost' pri riešení agendy a problémov Katedry. Ocenil prístup docenta Lysého k vedecko-pedagogickej práci, v ktorej sa odzrkadl'uje postoj klasického univerzitného učitel'a a vedca, uvedomujúceho si, že pre jej výkon je potrebný čas a sloboda. Hoci uviedol, že nemajú rovnaké názory v oblasti spoločenského života, práva a politiky, podotkol, že diskusia s docentom Lysým nikdy nebola strateným časom.

Do následnej diskusie za zapojil pán dekan, doc. JUDr. Eduard Burda, PhD., doc. JUDr. Juraj Vačok, PhD. z Katedry správneho a environmentálneho práva a napokon aj prof. JUDr. Jozef Klimko, DrSc. a doc. JUDr. Branislav Fábry, PhD. z Katedry teórie práva a sociálnych vied. Z rozpravy vyplynulo hned' niekol’ko sympatických záverov. Prvým z nich bol názor inauguranta, že nepovažuje za správne, ak sa presadzuje egocentrický pohl'ad na dejiny, ktoré vykladáme vlastným spôsobom. Upozornil na to, že by sme na nich

4 Oponentský posudok prof. JUDr. Petra Mosného, CSc. z 30. júla 2020.

$5 \quad$ Oponentský posudok prof. JUDr. Ladislava Vojáčka, CSc. z 9. augusta 2020. 
nemali hl'adiet' z pozície advokáta, ale sudcu. V súvislosti so svojou inauguračnou prednáškou nabádal na primerané zohl'adnenie českej a mad'arskej argumentácie a vcítenie sa do ich pozície. Dospel k tomu, že v prípade výchovy k jedinej správnej interpretácii dejín študenti nebudú argumentačne pripravení na konfrontáciu vo vzt’ahu k odlišným názorom. Ďalší krásny záver skonštatoval na základe výsledkov diskusie profesor Klimko, podl'a ktorého v oblasti právnych dejín teda ešte naozaj nie je všetko definitívne preskúmané, stále sa objavujú nové pohl'ady, máme d’alšie výskumné témy na celé desat'ročia. Náš odbor má teda budúcnost'!

Potom, čo sa komisia vrátila z tajného rokovania a hlasovania, profesor Klimko vyhlásil výsledky, z ktorých vyplynulo, že komisia i oponenti jednoznačne odporúčajú vymenovanie docenta Miroslava Lysého za profesora. Tento výsledok následne potvrdila tajným hlasovaním aj Vedecká rada Právnickej fakulty Univerzity Komenského. Inaugurant sa na záver pod'akoval oponentom i komisii, čo mu mnohí členovia Vedeckej rady odplatili srdečnou gratuláciou. Ku gratulácii sa pripájame aj my a želáme pánovi docentovi ešte vel'a d'alších tvorivých a vedeckých úspechov.

Q. B. F. F. F. Q. S.

doi: 10.14712/2464689X.2020.44

Martin Gregor 